\title{
THE INSTITUTE OF JAZZ STUDIES: A UNIQUE RESOURCE
}

\author{
BY MARIE P. GRIFFIN
}

Mrs. Griffin is librarian at the Institute of Jazz Studies

The Institute of Jazz Studies (IJS) was founded in 1952 by the late Dr. Marshall Stearns, a professor of medieval literature at Hunter College and author of two basic jazz studies, ${ }^{1}$ in conjunction with a group of musicians, scholars, critics, collectors, and jazz devotees. In 1966 the board of the institute selected Rutgers University as its permanent academic home and the collection of some 25,000 jazz sound recordings, books on jazz, clippings, photographs, African instruments and memorabilia was transferred to Rutgers in that year, shortly before Dr. Stearns' death.

The autonomous status of the institute was assured by the terms of the agreement bringing it to Rutgers. Certain conditions were established: I) the Institute of Jazz Studies was to continue as a separate entity, not as part of an existing academic department (this stipulation was made because in most academic music departments in the Uni ed States, jazz does not have the status of Western art music, and the institute board wanted to make certain that jazz music remained the primary focus of the collection) ; 2) the university was to house and maintain the collection and to encourage its growth; and 3) the collection was to be accessible.

After a year in storage, the collection was moved to the basement of the John Cotton Dana Library on the Newark campus. Charles Nanry, then an instructor in the Department of Sociology, University College, ${ }^{2}$ was appointed part-time administrator, and acting curators were employed to service the collection.

${ }^{1}$ Marshall W. Stearns, The Story of Jazz (New York: Oxford University Press, 1956) and Jazz Dance: the Story of American Vernacular Dance, co-authored with his wife Jean Stearns (New York: Macmillan, [1 968]).

2 Dr. Charles Nanry is now Dean of University College, Newark. Other administrators who played important roles in establishing the institute at Rutgers include David A. Cayer, now Vice President for Research Administration and co-editor, with Dr. Nanry, of the Annual Review of Jazz Studies, and William M. Weinberg, now chairman of the Industrial Relations and Human Resources Department, Institute of Management and Labor Relations, and Chairman of the IJS Advisory Board. 


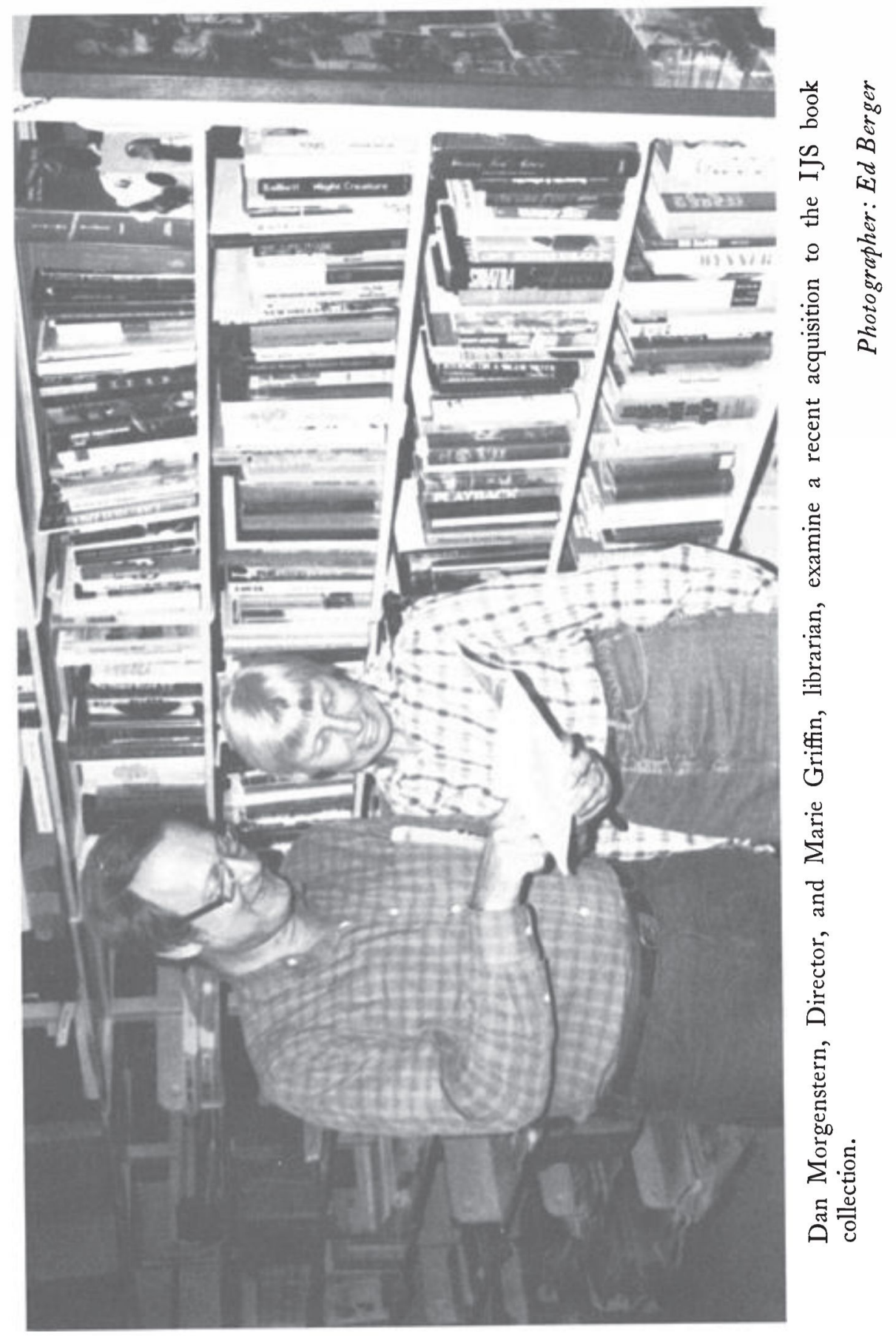


Community support contributed to making the institute's resources accessible. The Newark chapter of Soroptomists, an organization of business and professional women, donated a considerable sum of money for the purchase of shelving and the institute's first listening-taping equipment. While housed at the Dana Library, the collection was expanded through donations of significant materials from such well-known jazz authorities as Rudi Blesh, Nat Hentoff, Dan Mahoney, Leonard Feather, Robert Reisner, and Orrin Keepnews and from the estates of the late George Hoefer, Walter C. Allen and Charles Edward Smith. ${ }^{3}$ The tradition of bringing jazz to the community was also initiated during these years. A grant from the Sears-Roebuck Foundation enabled the institute to support a jazz week of concerts and lectures in seven Newark schools.

Bassist-educator Christopher White was the first full-time director of the institute. During his tenure, the institute was moved in 1975 to its present spacious location on the first floor of the newly-renovated Bradley Hall on the Newark campus. The larger quarters make the collection more accessible for research and study, for curriculum support of courses in jazz music, Afro-American studies and related subjects, and for expanding the influence of the institute in the promotion and appreciation of jazz music.

Dan Morgenstern, well-known jazz writer and former editor of Down Beat, ${ }^{4}$ has been the director since 1976 . The position of curator was officially added in 1978. Edward Berger, whose comprehensive discography of the composer, arranger, band-leader and performer Benny Carter is slated for publication in 1982 , has been curator since that time. The IJS collection has continued to grow through the acquisition of jazz releases from record companies, jazz books from publishers, subscriptions to periodicals, trading of duplicate materials with other archives and donations from private individuals and estates. During the past five years significant materials have been donated, including the Albert McVitty, Phillip Nash, Richard Yaffe and Fred Dachowitz sound recording collections, a variety of materials from George Simon and Michael Cuscuna, and band arrangements from the family of Muggsy Spanier.

A cooperative venture in sharing music resources brought the John Dale Owen collection to the institute on permanent loan from the Uni-

\footnotetext{
${ }^{3}$ Space does not permit a complete listing of the many friends of the institute whose donations have expanded the collections; for example, William H. Helfand, now senior vice-president of Merck, Sharpe and Dohme International, was an early contributor.

${ }^{4}$ Down Beat (Chicago: 1934- ).
} 
versity of Wisconsin-Milwaukee. ${ }^{5}$ This collection of approximately I0,000 sound recordings include commercial recordings from the I 920 s through the early I950s, transcriptions of radio programs and private recordings, and a substantial number of V-discs. (V-discs were special $78 \mathrm{rpm}$ recordings made for the Armed Forces during World War II; since the musicians were not paid for these performances, the recordings were never distributed commercially and the masters were destroyed at the end of the war.) When this collection arrived in Newark, the IJS staff wondered why the V-disc component was smaller than had been anticipated. The mystery was solved in November 1980 when the director received a note from Dr. Owen's widow offering the remainder of Dr. Owen's collection of $\mathrm{V}$-discs to the institute.

In 1980 the institute received $\$ 25,000$ under a United States Department of Health, Education and Welfare Title IIC grant awarded to the Rutgers University Libraries to enhance the university's research resources. These grant funds were used to expand the collection of recorded sound by purchasing out-of-print recordings, European and Japanese releases, and certain collector's items; to augment the book collection by purchasing 250 books on jazz including foreign imprints and ephemeral materials; to enhance the periodical collection by ordering back issues where needed and by adding important current subscriptions; to obtain microfilm copies of dissertations on jazz; to subscribe to clipping services covering seven metropolitan areas in the United States; and to purchase copies of rare, historical jazz film footage. Preservation activities under the grant included the copying of rare photographs, obtaining materials for the preservation of deteriorating periodicals and pamphlets as well as plastic envelopes to preserve photographs, and the purchase of additional wood storage units for shelving the $78 \mathrm{rpm}$ recordings. In addition, moving and insurance costs incurred in the transfer of the Owen collection from the University of Wisconsin-Milwaukee to Newark were paid from this fund.

\section{The IJS Collection}

The collection of jazz phonograph records now comprises more than 60,000 discs, primarily $78 \mathrm{rpm}$ and $331 / 3 \mathrm{rpm}$ recordings but including

\footnotetext{
5 For a detailed account of this innovative project for sharing resources see Richard $\mathbf{E}$. Jones, "Cooperative Venture in Sharing Music Resources," Notes, 37 (September 1980), pp. 174-1 76.
} 
some $45 \mathrm{rpm}$ discs as well as $16 \mathrm{rpm}$ transcriptions. The recorded sound collection also includes audio tapes, cylinder recordings, and piano rolls. For jazz, this uniquely American music which is characterized by improvisation and individual interpretation, the recorded performance, not the composer's score or the arrangement, is the primary source for research and study. Thus, this collection of recorded jazz music, the largest under university auspices anywhere, is the very heart of the archive.

The supplementary materials provide the reference sources and research tools needed to access this fabulous resource of recorded sound and to understand and appreciate its roots, its development and, especially, the musicians whose contributions as individual performers and as members of performing groups, created this vital music.

\section{Monographs}

The institute houses a library of more than 3,000 books on jazz and related subjects. The reference component of this library is historically important, ranging from Dr. Stearns' early works to current scholarship and including analyses of jazz music by prominent musicologists such as Gunther Schuller. ${ }^{6}$ Dissertations, primarily microfilm copies but including gifts from doctoral candidates who did much of their preparation at the institute, provide access to current research. Numerous rare and outof-print books are included in the collection; some of these have been reprinted by $\mathrm{Da}$ Capo Press. Large runs of manufacturers' catalogs, ${ }^{7}$ as well as an extensive selection of Schwann catalogs, ${ }^{8}$ help both staff and researchers identify recorded performances. The collection of discographies dates from Delaunay's seminal work, published in $1936,{ }^{9}$ and includes the latest editions of the comprehensive discographies compiled by

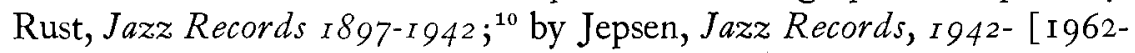
1969]; ;1 and by Bruyninckx, 60 Years of Recorded Jazz, I9I7-r $977 ;^{12}$ as well as an extensive selection of specialized discographies focusing on individual artists.

${ }^{6}$ Gunther Schuller, Early Jazz: Its Roots and Musical Development (New York: Oxford University Press, ig68).

7 Manufacturers' catalogs in the collection include Brunswick, Columbia, Decca, His Master's Voice (England), and Victor (includes Bluebird).

${ }^{8}$ Long Playing Record Catalog (Boston, etc.: W. Schwann, 1949- ).

${ }^{9}$ Charles Delaunay, Hot Discography, edited by Hot Jazz (Paris, 1936).

10 Brian Rust, Jazz Records $1897^{-1942,} 4^{\text {th }}$ ed. (London: Storyville Publications, 1978, ci 977 ).

11 Jorgen Grunnet Jepsen, Jazz Records I942- (Denmark, K. E. Jnudsen, I965- ).

12 Walter Bruyninckx, 60 Years of Recorded Jazz, 19x7-1977 (Belgium: 1978-) 


\section{The IJS Jazz Register and Indexes}

A significant addition to jazz discography is the innovative jazz cataloging/indexing project initiated at the institute in the fall of 1978 with grant support from the National Endowment for the Humanities. ${ }^{13}$ This computerized cataloging/indexing project is particularly distinctive because it combines the discographical research required for archival cataloging with conformance to national cataloging and computerization standards. The project staff catalogs each recorded performance on a phonograph record, normally each side of a $78 \mathrm{rpm}$ disc and each track of a $331 / 3 \mathrm{rpm}$ recording. Catalog records are input to OCLC, ${ }^{14}$ a national bibliographic data base, using the MARC music format. ${ }^{15}$

This analytical cataloging identifies, in machine-retrievable locations in the catalog record, all the essential elements of a recorded jazz performance: the names of all performers, performing groups, composers, lyricists, arrangers, conductors, and directors; the instrumental and vocal configuration; the specific date and place of performance; the title of the selection, as determined from the first published edition of the music, and variant titles appearing on record labels, liner notes, or album covers; the label name and issue designation; the matrix and take number where applicable $;^{16}$ the date of issue and/or reissue; and the physical characteristics of the recording (kind of sound, i.e. stereo/mono/acoustical,

${ }^{13}$ This project was begun under the National Endowment for the Humanities (NEH) Research Collections Program Grant RC-30601-78-597 and is continuing under NEH Grant RC-ooro5-79-I404. NEH funding for 1981-1982 matches grants from the New Jersey Jazz Society, the Franklin Mint Record Society and the Rutgers University Foundation. The author is supervisor of the project; Vincent Pelote and Walter Parker are the catalogers/discographers.

14 Online Computer Library Center, Inc. (OCLC), January 198I- . Established in 1967 as the Ohio College Library Center, the bibliographic network is commonly identified as OCLC since its incorporation as OCLC, Inc., in 1977. Rutgers is now a member of RLIN, the bibliographic network of the Research Libraries Group. When this project began, however, OCLC was the only bibliographic utility accepting catalog records in the MARC music format. It is anticipated that the IJS data base will be added to the RLIN data base at the conclusion of the grant period.

${ }^{15}$ Library of Congress, MARC Development Office, Music: a MARC Format (Washington, D.C.: for sale by the Superintendent of Documents, U. S. Government Printing Office, 1976) and Addenda I-3 (Washington, D.C.: Library of Congress, 1976-1980). Effective I January, I98I, Music, a MARC Format has been incorporated in the composite MARC document, MARC Formats for Bibliographic Data (Washington, D.C.: Library of Congress, 1980 ).

${ }^{16}$ In producing a $78 \mathrm{rpm}$ recording the matrix and take number was inscribed in a wax disc from which the metal master or matrix was made. The matrix was used to make a stamper from which to stamp the grooves in the shellac disc. The matrix and take number usually appears near the center of the disc, between the hole and the end of the groove area, but there are many variations from this practice. 


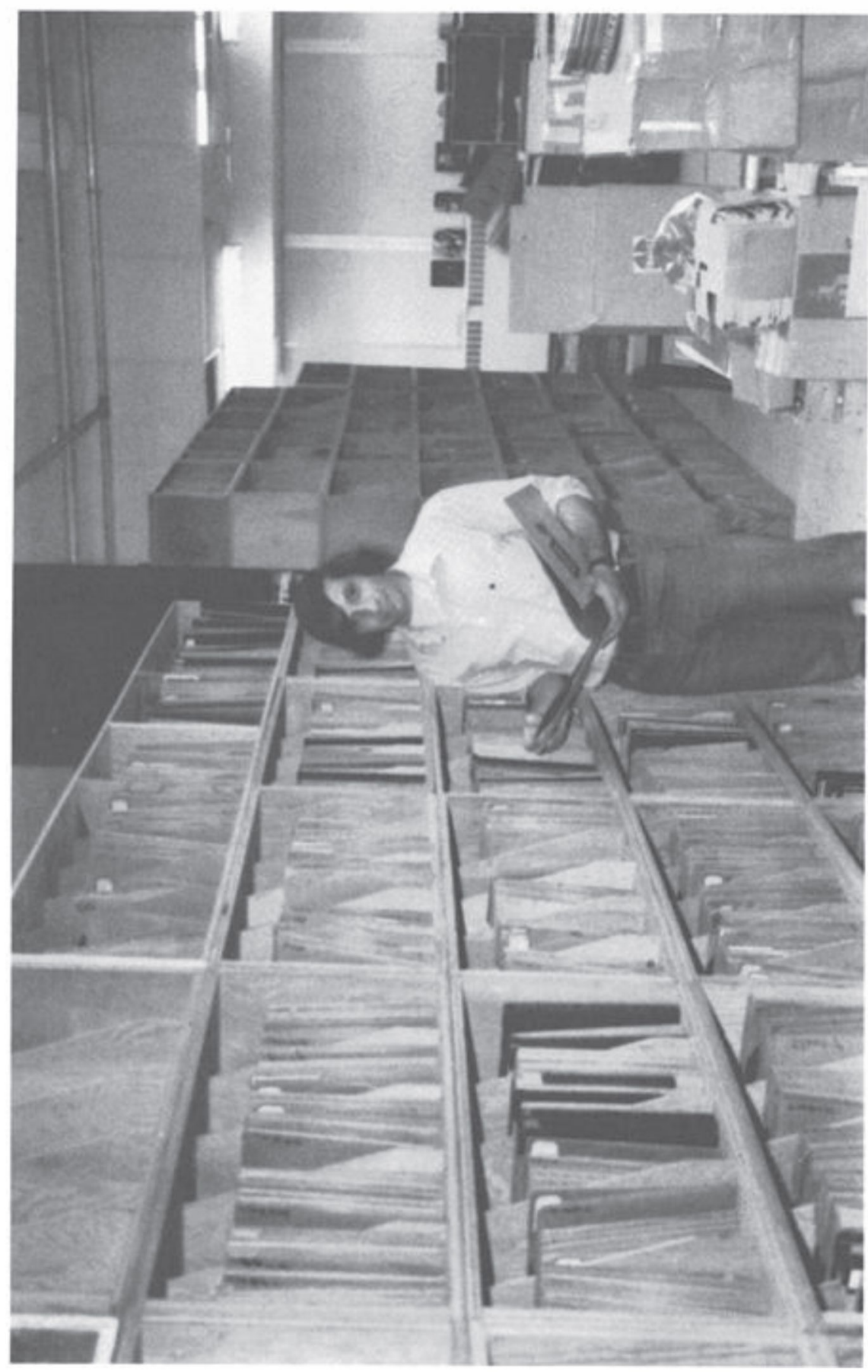

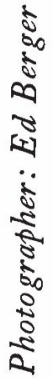

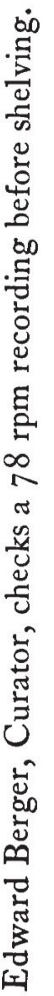


speed, dimensions, description of label). Cataloging procedures conform to Anglo-American Cataloging Rules, ${ }^{17}$ and the catalog records are input to the data base from worksheets designed to conform to the input requirements of the MARC music format. ${ }^{18}$

The initial fourteen-month project concentrated on jazz recordings of the acoustical recording period (the recording years prior to $1925 / 1927$ when electrical microphones and amplifiers became generally available to recording studios); early performances by such jazz greats as Louis Armstrong, Fletcher Henderson, Sidney Béchet and Bessie Smith have been identified in this cataloging. The current phase of the project emphasizes the cataloging of $331 / 3 \mathrm{rpm}$ recordings, particularly performances recorded between 1962 and 1969 which are not included in the major discographical sources, reissues produced in the I970s containing important historical performances, and non-studio recordings including airchecks, transcriptions, private recordings and alternate takes of previously issued material. Therefore, this cataloging provides access to significant segments of the IJS recorded sound collection, which are not covered in existing discographies.

Magnetic tapes containing IJS catalog records are received monthly at the Rutgers Library Computer Center. From the cumulated tapes which comprise the IJS data base, the Library Computer Center produces the IJS Jazz Register and accompanying indexes by performer/ title; performer/performing group; composer, arranger, director; title, including variant titles; and label name and issue number (comparable to a shelf list) on computer-output-microfiche (COM) with an effective reduction ratio of $42: \mathrm{I}$. The open-ended register represents, in natural language, all the IJS catalog records produced up to and including the latest monthly tape. Entries are arranged by IJS number, ${ }^{19}$ and the register is the source document for the indexes, which are keyed to the register by IJS number. The indexes provide direct access to the es-

${ }^{17}$ Anglo-American Cataloging Rules, North American text (Chicago: American Library Association, 1967) and, since I January, I981, Anglo-American Cataloguing Rules, 2nd ed. (Chicago: American Library Association, 1978).

${ }^{18}$ Music, a MARC Format.

19 The IJS number identifies both the physical item and the recorded performance. Example: IJS Dooooor.o I-The "IJS" sigla identifies the Institute of Jazz Studies. The "D" indicates that this is the disc collection; the "O0000I." number identifies the physical disc, in this instance the first disc cataloged; the decimal number identifies the recorded performance on the disc, in this example ".ox" indicates the performance recorded on the first track of the disc. 
sential discographical information needed for reference and research. The components of the single-line indexes are fixed-length character strings, each identified in the machine-readable record by a distinctive field and subfield location. The flexibility of this approach permits many permutations of the data in a variety of configurations. Additional indexes (for example, by date and/or place of performance) could be produced with minimal additional programming. Moreover, the use of the register/indexes format to provide bibliographical and discographical information and to distribute cataloging data is in accord with national and international bibliographic control. ${ }^{20}$

\section{Periodicals}

The institute has extensive holding of jazz periodicals from throughout the world, specifically the United States, Canada, most European countries, Japan, and Australia. Many of these periodicals are extremely rare; some have been microfilmed by Greenwood Press and are, therefore, available in microfilm at IJS and other institutions. Portions of the periodical collection, such as early issues of Down Beat and Melody $M_{a k e r^{21}}$ which were published in tabloid form, are deteriorating. A preservation program was begun this spring with the microfilming of early issues of Down Beat by the Special Collections Department at the Alexander Library, Rutgers.

Access to the information in these periodicals is possible primarily because of the expertise of the institute staff. No comprehensive index to jazz periodicals existed prior to the publication of Jazz Index in $1977 .^{22}$ Some periodicals, Down Beat, for example, do include annual indexes. Also, a small number of jazz periodicals are indexed in Music Index. ${ }^{23}$ Jazz Index, which provides world-wide coverage of jazz periodicals is, however, the most comprehensive. Discographies which have appeared in jazz periodicals are included in Daniel Allen's Bibliography of Discographies. ${ }^{24}$

${ }^{20}$ Judith G. Schmidt, "Library of Congress Plans for the National Union Catalog," Library of Congress Information Bulletin, vol. 40, no. 3 (January 16, 198 I), pp. 35-36; and J. McRee Elrod, "Universal Availability of Bibliographic Records," IFLA Journal, no. 4 (1978), pp. 347-350.

${ }^{21}$ Melody Maker (London: 1926- ).

${ }^{22}$ Jazz Index (Frankfurt-am-Main, Germany: N. Ruecker, I977- ).

${ }^{23}$ Music Index (Detroit: 1949- ).

${ }^{24}$ Daniel Allen, Bibliography of Discographies (New York: Bowker, 1977). 
The institute publishes The Journal of Jazz Studies, ${ }^{25}$ the only English-language scholarly publication devoted to jazz. From 1973 through I98I this was a semi-annual publication; beginning in 1982 the journal will be published annually under the title Annual Review of Jazz Studies. Dan Morgenstern, the present director of the institute, is review editor of the journal. Members of the IJS staff and the Advisory Board of the institute are frequent contributors to this journal.

\section{Oral History}

The Jazz Oral History Project, initiated by the Jazz Panel of the National Endowment for the Arts and administered for a number of years by the Division of Performing Arts of the Smithsonian Institution, Washington, D.C., was transferred to the institute in 1979 with continuing support from the Music Program of the National Endowment for the Arts. ${ }^{26}$ This project features five to seven hour in-depth interviews with notable jazz musicians. In describing their own careers some of the musicians interviewed also offer additional insights into the music and lives of the great jazz innovators, luminaries such as Duke Ellington and Fletcher Henderson. Tapes of the more than ninety interviews now completed under this project have been edited and transcribed and are, therefore, also available for reference and research in manuscript form.

\section{Research Files}

The clipping files are divided into two sections: a performer file and a topic file. The performer file is arranged alphabetically by performer; an index to the topic file provides a guide to this resource. ${ }^{27}$ The clipping files date from the early I 900s; many of the clippings were originally in Dr. Stearns' collection. These files have been continually expanded through contributions from staff members, the institute board, and other friends of the institute. Clipping services are utilized when funds are available. A distinctive feature of the performer files is the inclusion of biographical information from the performers themselves; this data was

25 The Journal of Jazz Studies (New Brunswick, N.J.: Transaction Periodicals Consortium, I $973-198 \mathrm{I}$ ).

${ }^{26}$ Writer-editor Ron Welburn is coordinator of the Jazz Oral History Project. Phil Schaap is assistant coordinator, and Jeanette Gayle is clerk-typist.

27 The index, "Topic File Subject Headings: Indexes and Master List," was compiled by Robert W. Kenselaar, formerly assistant curator at the institute. 


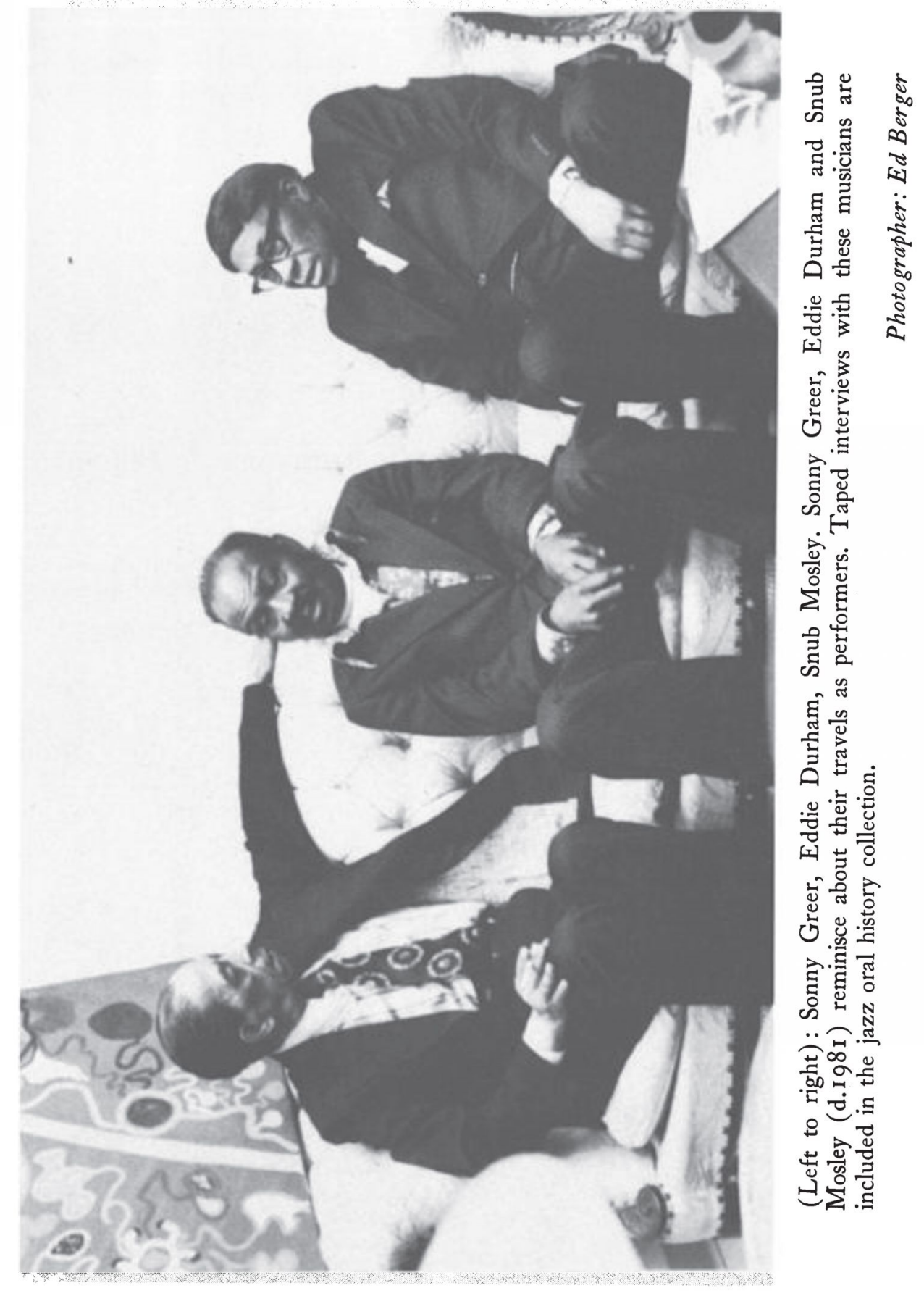




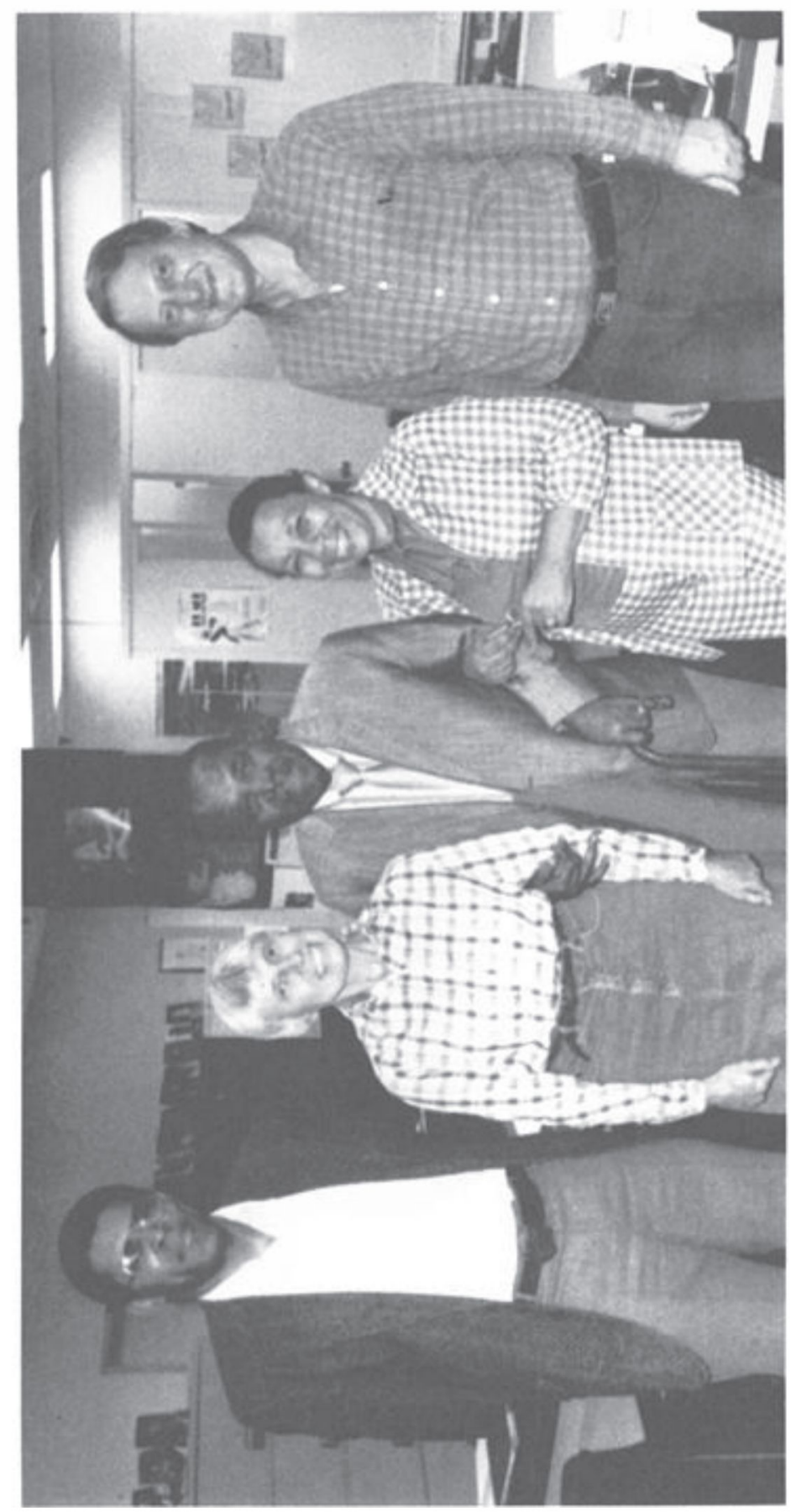

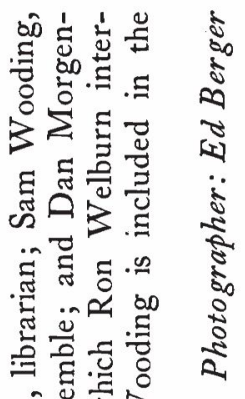

है

里

-

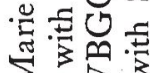

$\sum \sum 3$

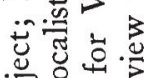

군

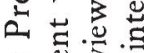

놀

芯芯志的

牙 00

그용

กั

节的要

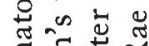

莺芯芯

แี $\times$ की

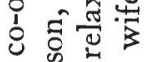

E.

空

도음

एँ

व

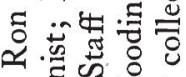

‥

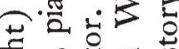

है

I

ภ䒕司

$\triangle \stackrel{0}{0}$

出可良

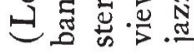


solicited from the performers by Leonard Feather prior to the publication of the second edition of his Encyclopedia of Jazz. ${ }^{28}$

The photograph collection, also arranged by performer, is a resource treasured equally by jazz buffs, visitors to the institute, students, and researchers. Plastic envelopes help to preserve and protect these photographs. In addition, a number of rare photographs have been copied.

\section{Printed Music and Music Manuscripts}

Because improvisation and individual interpretation are essential elements of jazz music, a prevailing misconception holds that jazz musicians play whatever comes into their heads and lack formal musical training. In fact, very few jazz musicians have no formal musical background; many performing artists are also composers; and creative geniuses, such as Louis Armstrong and Charlie Parker who had little formal training, learned their instruments under a self-imposed apprenticeship which included extensive practice. The IJS collection of jazz music includes big band and ensemble arrangements, music scores, transcriptions of recorded solos in musical notation, ragtime compositions, piano music selections, instructional music, song books, and sheet music.

\section{Film}

The film collection consists primarily of excerpts of film footage from feature films in which jazz artists performed and short films featuring jazz bands. The institute also has a limited number of private films of performances and TV broadcasts and some videotapes of performances in the r 960 s and the r970s.

\section{Realia}

Marshall Stearns' collection of African instruments includes some of the precursors of today's xylophone and percussion instruments and reflects Dr. Stearns' interest in the African origins of jazz music. Memorabilia now on exhibit at IJS include such diverse items as Willie "The Lion" Smith's derby and Roy Eldridge's rhinestone-studded trumpet mouthpiece. A collection of early phonographs permits the playing of early $78 \mathrm{rpm}$ "fox trots" and "Charlestons" in an atmosphere reminiscent

${ }^{28}$ Leonard Feather, The New Edition of the Encyclopedia of Jazz (New York: Horizon Press, i 960 ). 
of the "jazz age" of the I920s. Paintings by jazz clarinetist Pee Wee Russell share wall space with portraits of Marshall Stearns and Duke Ellington, numerous other works of art, and an assortment of colorful posters. Sculptures include a wooden statue of Charlie Parker, by sculptor Julie MacDonald.

\section{IJS Facilities}

The institute is housed in spacious quarters on the first floor of Bradley Hall on the Rutgers Newark campus. A large open room provides both an exhibit area and space for study and research. Meetings and classes for groups numbering fifteen individuals can be accommodated in this area. Staff members have offices along the east wall, and an office is provided for the oral history project. There is restricted access to the stacks housing the recorded sound collection which is shelved in a large room adjoining the public area. Because new acquisitions continue to expand this collection, additional shelving and space for this shelving will soon be required.

Two small rooms are equipped with listening-taping facilities. Although newer and more sophisticated equipment is desirable, present equipment permits the staff and patrons of the institute to listen to the various configurations of recorded sound included in the collection (cylinders, hill and dale disc recordings, ${ }^{29} 78,45,33 \frac{1 / 3}{3}$ and $16 \mathrm{rpm}$ disc recordings, and piano rolls). Recordings are taped for patrons only if the recorded performance desired is unavailable commercially; 78,45 , $331 / 3$ and $16 \mathrm{rpm}$ recordings can be taped on either standard cassettes or reel-to-reel audio tapes at $3 \frac{3 / 4}{4}$ or $7 \frac{1}{2}$ ips. Patrons expecting to use the listening/taping facilities are requested to make appointments in advance so that their needs can be adequately accommodated.

Small rooms provide for the use of the computer terminal, microfiche and microfilm readers. Although this equipment is primarily for staff use, patrons needing these facilities can be accommodated.

\section{Reference and Research}

The institute's collections are not only a valuable resource for musicologists studying jazz music but also a rich and varied source of ma-

${ }^{29}$ Hill and dale recordings contain vertical rather than lateral grooves. All cylinder recordings and some early discs were recorded in this manner, the playing speed is approximately $78 \mathrm{rpm}$. 


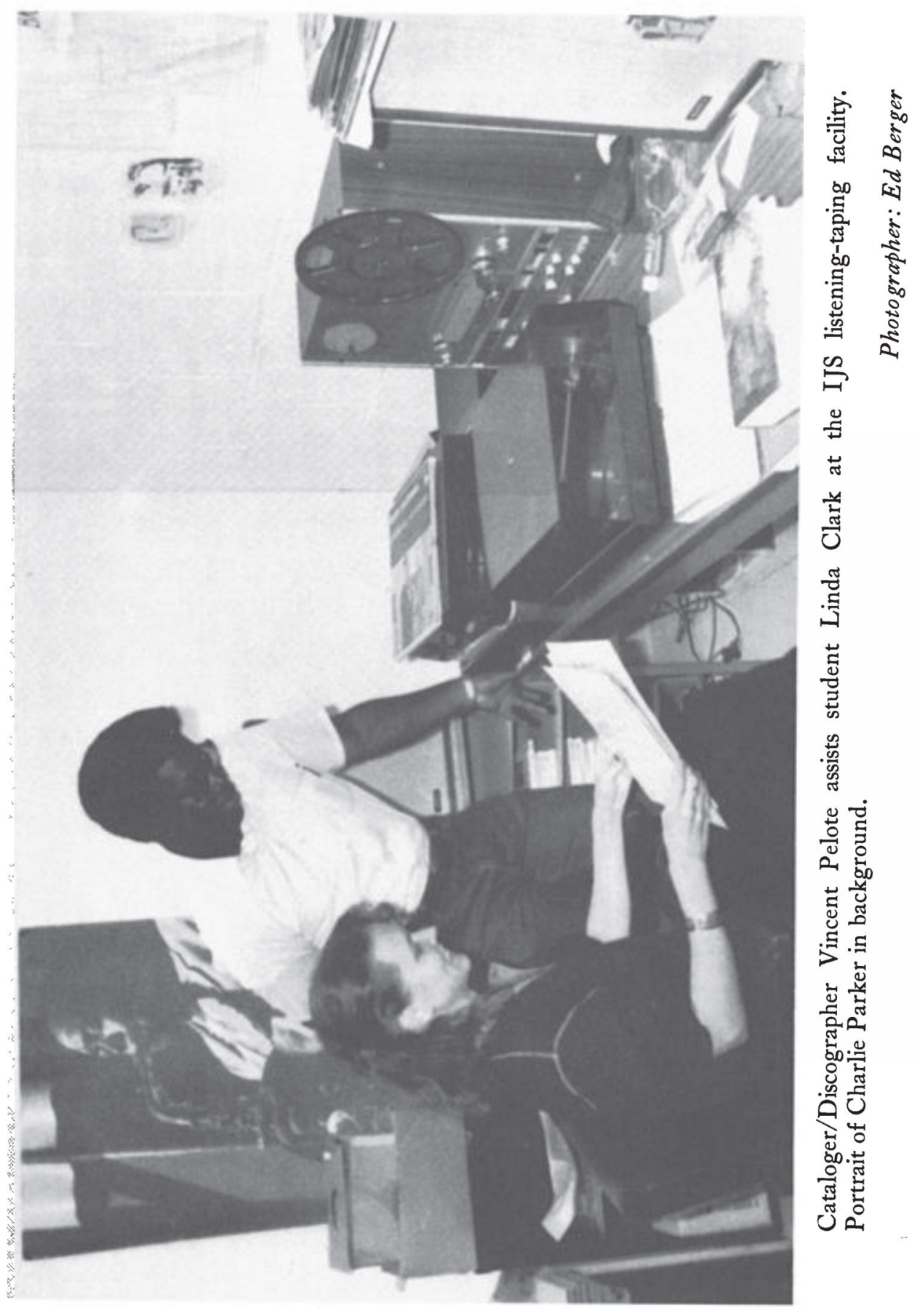


terials for researchers in ethnomusicology, social studies, Afro-American history, sound documentation and related areas.

Student users range from the undergraduate writing a term paper on a jazz-related topic to doctoral candidates completing their dissertations. Jazz scholars from all sections of the United States and many foreign countries find the institute's resources essential to their research both for the updating and/or compilation of jazz and jazz-related discographies and bibliographies and for the documentation and verification of data prior to the publication of journal articles and monographs. Researchers include retired individuals free to pursue their avocation in a scholarly fashion.

Topics are as diverse as the varied backgrounds of these scholars suggest. Although undergraduates taking their first jazz course tend to concentrate their research on prominent artists like Billie Holiday and Charlie Parker, doctoral students frequently seek more esoteric material. A student from the University of Washington, Seattle, found rare $45 \mathrm{rpm}$ recordings featuring jazz organist Luis Rivera in the institute's collection. Among the frequent visitors to the institute are free-lance writers doing research on women in jazz. A librarian from England traveled to Newark to obtain the citations necessary to update his bibliography of American music. ${ }^{30}$ A discographer from Finland was introduced to the computer at IJS; he was able to locate numerous recordings by Louis Armstrong for his discography, which will update Jepsen's Jazz Records I942- $\quad .31$

Jazz courses are offered at Rutgers' Livingston College, at Rutgers Newark and, beginning with the I98 I fall semester, at the Mason Gross School of Performing Arts. The institute enjoys a close working relationship with the faculty at these divisions. Broad curriculum support is a highlight of this collaboration. Although the institute does not offer courses, class sessions can be, and frequently are, scheduled at IJS. In addition, consultation services are provided to other archives and research institutions.

The location of the institute, which can be reached by public transportation from either Newark International Airport or New York City, ensures that performers, too, can use IJS facilities. Aspiring performers

\footnotetext{
${ }^{30}$ David Horn, The Literature of American Music in Books and Folk Music Collections: a Fully Annotated Bibliography (Metuchen, N.J.: Scarecrow Press, 1977).

${ }^{31}$ Jazz Records $1942-$
} 
strive to improve their musical technique by studying the performances of the acknowledged masters of their instruments. Established performers find in the IJS recorded sound collection and research files evidence of performances they themselves have forgotten. IJS has involved professional musicians in educational roles, first by inviting trumpeter-composer Donald Byrd to be musician-in-residence as performer and coach of a student band, later by helping to plan a cooperative program in which jazz performers taught improvisation to high school musicians. Close collaboration with jazz artists who are also faculty members at Livingston College adds a professional dimension to jazz music courses at Rutgers.

Television and radio broadcasters find the resources of the institute extremely valuable for the preparation of $\mathrm{TV}$ and/or radio programs. The institute enjoys a close working relationship with radio station WBGO in Newark and produces a program, "Jazz From the Archives," which is aired Sunday evenings from Io p.m. to I 2 midnight. Journalists and newspaper reporters frequently request information on the telephone in efforts to verify names of performers, dates of performance, producers, etc.

The recorded sound collection also serves as a resource for record companies engaged in major reissue programs. Research for special projects such as the Smithsonian Institution's archival series, New World Record's bicentennial series on recorded American music, and TimeLife's "Giants of Jazz" series requires the identification of alternate takes and various issues of recorded performances as well as aural comparisons.

\section{Related Services}

Since jazz was first introduced to Europe in the 1920's, and in Japan in the I960's, the music has been recognized as a unique American, specifically Afro-American, contribution to serious music. However, although jazz has, since its earliest days, brought black and white Americans together in a shared interest, the significance of jazz music in the development of Western art music was largely unrecognized by the academic community in the United States until the late 1960 s? $^{32}$ College and university courses in jazz music proliferated during the 1970's;

32 John Rockwell, "Does Jazz Qualify as 'Classical'?" New York Times (June 2 I, 1981), pp. 19, 24 . 


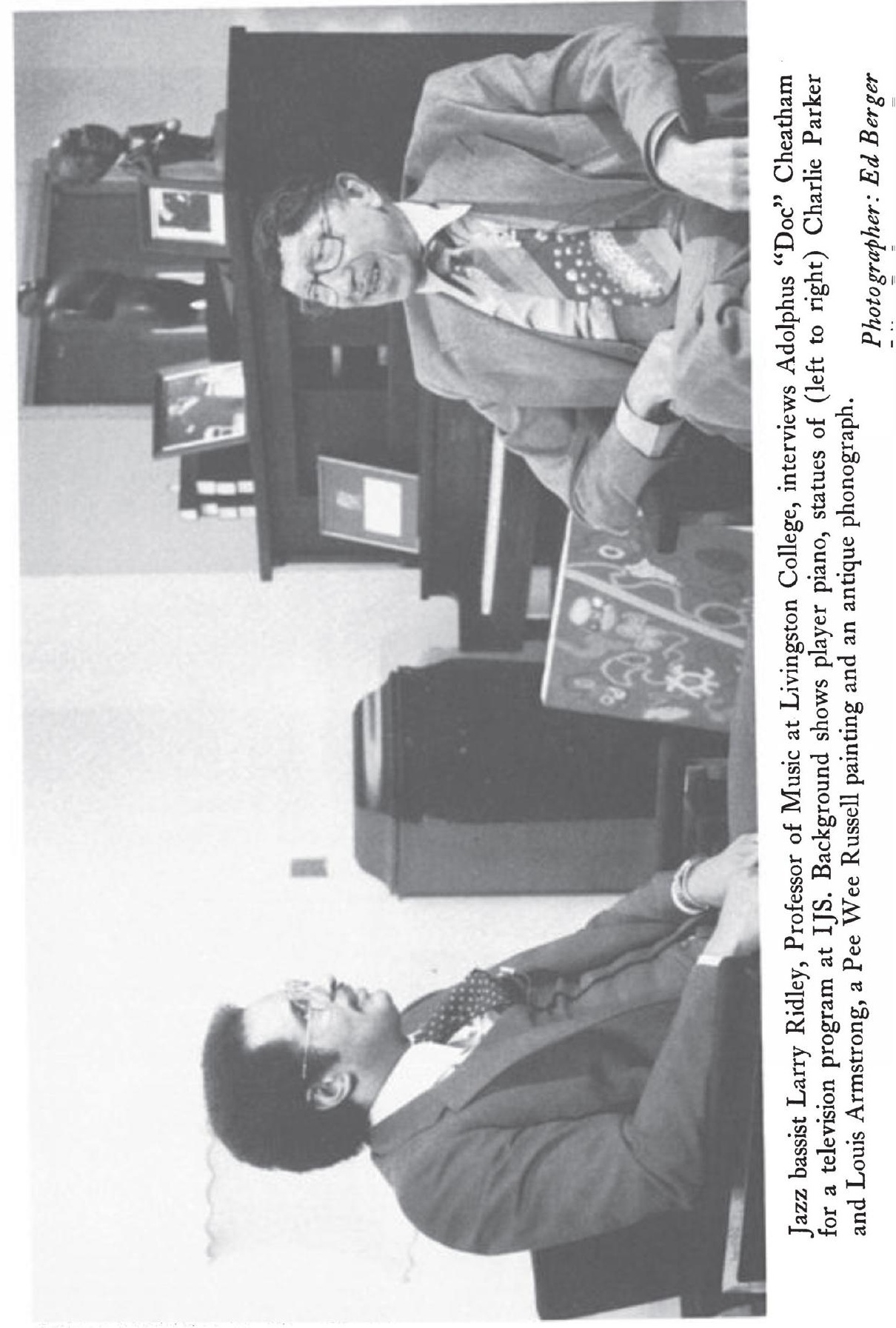


nonetheless, in many academic institutions jazz music remains outside the established music curriculum. The institute endeavors to give jazz music and musicians the recognition they deserve and to preserve and promote jazz in all its varied aspects. Since its inception, IJS has sponsored seminars and discographical conferences on a regular basis. In recent years seminars held in conjunction with the Newport-New York Jazz Festivals combine academic presentations and musical workshops with active participation by the general public. Grants from the New Jersey Council on the Arts have supported these seminars.

IJS cooperates in efforts to make jazz a living force in the community. The institute has sponsored or organized more than 200 concerts, including a notable series in collaboration with the Carnegie Hall Corporation and a series of concerts/workshops by major artists on the New Brunswick and Newark campuses of Rutgers, sponsored jointly with the Music Department of Livingston College. Since 1977 the institute has cooperated in the celebration of Jazz Week in the city of Newark, a celebration which includes concerts, special programming on WBGO, and other jazz-oriented events.

The continual expansion of the reference and research use of the institute reflects both the rise of jazz scholarship in the academic sector and the renewed popularity of the music in the concert hall, in the clubs, and in the activities of jazz societies in this country and abroad. That this diverse user community can be adequately served is a tribute to the expertise and dedication of the IJS staff. The Institute of Jazz Studies is a unique resource on the Rutgers Newark campus open to qualified researchers with or without institutional affiliation, as well as members of the general public. ${ }^{33}$

${ }^{33}$ The institute is open Monday through Friday between the hours of 9 a.m. and 5:30 p.m. Because of limited staff and listening facilities, an appointment is required (Phone: 201-648-5595).

The photographs accompanying this article have been taken by Edward Berger, curator at IJS. Permission to reproduce these must be obtained from Mr. Berger, Institute of Jazz Studies, Rutgers, the State University, 135 Bradley Hall, Newark, N.J. o7102. 